\title{
Use of glass waste in the production of metakaolin-based geopolymer submitted to room temperature and thermal curing
}

\author{
Utilização de resíduo de vidro na produção de \\ geopolímero de base metacaulim submetido a cura \\ ambiente e em estufa
}

\section{Cristiane do Bom Conselho Sales Alvarenga \\ Rosemary do Bom Conselho Sales \\ Rodrigo Barreto Caldas \\ Paulo Roberto Cetlin \\ Maria Teresa Paulino Aguilar}

${ }^{1}$ Cristiane do Bom Conselho Sales Alvarenga

${ }^{1}$ Universidade Federal de Minas Gerais Belo Horizonte - MG - Brasil

${ }^{2}$ Rosemary do Bom Conselho Sales

${ }_{2}$ Universidade do Estado de Minas Gerais Belo Horizonte - MG - Brasil

${ }^{3}$ Rodrigo Barreto Caldas ${ }^{3}$ Universidade Federal de Minas Gerais Belo Horizonte - MG - Brasil

${ }^{4}$ Paulo Roberto Cetlin ${ }^{4}$ Universidade Federal de Minas Gerais Belo Horizonte - MG - Brasil

${ }^{5}$ Maria Teresa Paulino Aguilar 5 Universidade Federal de Minas Gerais Belo Horizonte - MG - Brasil

Recebido em 09/08/20 Aceito em 08/08/21

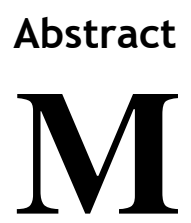

etakaolin is the principal raw material utilized in the synthesis of geopolymers, although its ratio of silica and alumina contents is not ideal. Normally, the $\mathrm{SiO}_{2}$ content is adjusted with the use of silicates present in the activating solution. An eco-efficient alternative would be the use of glass waste as an additional source of silica. This work evaluates the efficiency of the alkaline activation of metakaolin, using potassium hydroxide and silicate, with and without the substitution of $12.5 \%$ of metakaolin by microparticles of glass. The efficiency of the alkaline activation was evaluated by X ray diffractometry, spectroscopy in the infrared region with the Fourier transform, nuclear magnetic resonance spectroscopy of ${ }^{27} \mathrm{Al}$ and ${ }^{29} \mathrm{Si}$, specific mass and compressive strength. The results indicate the occurrence of geopolymerization with and without the use of glass waste. It was observed that the substitution of $12.5 \%$ favors the mechanical performance of the compounds at 28 days, with increases by $37 \%$ and $47 \%$ in the mechanical strength of the material with thermal curing and ambient temperature curing, respectively.

Keywords: Metakaolin. Glass waste. Potassium hydroxide. Alkaline activation. Geopolymerization.

\section{Resumo}

O metacaulim é a principal matéria-prima utilizada na síntese de geopolímeros, embora a relação entre os teores de sílica e alumina não seja a ideal. Normalmente, o teor de $\mathrm{SiO}_{2}$ é ajustado com o uso de silicatos presentes na solução ativadora. Uma opção ecoeficiente seria o uso de resíduos de vidro como fonte adicional de sílica. Este trabalho avalia a eficiência da ativação alcalina do metacaulim, utilizando hidróxido e silicato de potássio, com e sem substituição de $12,5 \%$ de metacaulim por micropartículas de vidro. A eficiência da ativação alcalina foi avaliada por difratometria de raios $x$, espectroscopia na região infravermelha com transformada de Fourier, espectroscopia de ressonância magnética nuclear do ${ }^{27} \mathrm{Al} e^{29} \mathrm{Si}$, massa específica e resistência à compressão. Os resultados indicam a ocorrência de geopolimerização com e sem uso de resíduo de vidro. Observou-se que a substituição de 12,5\% favorece o desempenho mecânico dos compósitos aos 28 dias, com aumentos de $37 \%$ e $47 \%$ da resistência mecânica do material com cura em estufa e na temperatura ambiente, respectivamente.

Palavras-chave: Metacaulim. Resíduo de vidro. Hidróxido de potássio. Ativação alcalina. Geopolimerização. 


\section{Introduction}

Geopolymers are an advantageous alternative to Portland cement in certain applications. Depending on the raw materials and the processing conditions, these materials can present high initial compressive strength, low shrinkage, greater/lower consistency, resistance to acid and sulfate attack, and better thermal stability at high temperatures (RIAHI et al., 2020; SINGH; MIDDENDORF, 2020; TORRES-CARRASCO; PUERTAS, 2017). In addition, these binders present long-term mechanical strength and durability greater than Portland cement (DAVIDOVITS, 2017; HÁJKOVÁ, 2018; YASERI et al., 2017).

Geopolymer binders can be obtained by the alkaline activation of aluminosilicate-rich raw materials (precursors) with low calcium content, such as calcined clays (especially metakaolin) and fly ashes, forming an amorphous or nanocrystalline sodium-aluminosilicate hydrates gel (N-A-S-H), with a tridimensional structure charge-balanced by cations from an alkali activator (BERNAL; PROVIS, 2014; PROVIS; LUKEY; VAN DEVENTER, 2005). Geopolymers can be synthesized following two routes (FENG; PROVIS; VAN DEVENTER, 2012). In the usual two-part method, the alkaline activator is typically a solution of sodium hydroxide, potassium hydroxide or sodium or potassium silicates in high concentrations (LAHOTI; TAN; YANG, 2019). In the one-part method, a dry mixture of an alkaline source powder and a precursor receive water addition (KOLOUŠEK et al., 2007).

Studies by Dimas, Giannopoulou and Panias (2009) indicate that it is necessary to add a silica source in most precursors to adjust the $\mathrm{Si} / \mathrm{Al}$ ratio and consequently improve the performance of the materials produced. A proportion of Si: Al of 3:1 is considered adequate (YASERI et al., 2017). The presence of a fine and amorphous silica source could increase the formation of Si-O-Si bonds in the binder, which becomes more compact and with greater mechanical strength (GAO et al., 2014; HE et al., 2016).

Geopolymers can become eco-efficient binders for civil construction if sourced from local raw materials (ABDULKAREEM et al., 2021; ADESANYA et al., 2021; PROVIS, 2018). According to Singh, Kumar and Rai (2020), any residuals that contain aluminosilicates, when treated with alkaline solutions, can produce geopolymer cement. The incorporation of residues with an adequate $\mathrm{Si} / \mathrm{Al}$ ratio could minimize the proportion of silicate solution used (HABERT; D'ESPINOSE DE LACAILLERIE; ROUSSEL, 2011; YASERI et al., 2017), besides promoting adequate disposal of an environmental liability (LIU et al., 2019; THO-IN et al., 2018). Studies by different authors analyze the use of glass as a precursor for obtaining geopolymers (CYR; IDIR; POINOT, 2012; PAVLIN et al., 2021) and indicate that a percentage of CaO and low $\mathrm{Al}$ content in the precursor waste glass promote the formation of calcium aluminosilicate, hydrate gel (C-A-S-H), together with N-A-S-H, influencing the mechanical properties of the activated material (THO-IN et al., 2018; TORRES-CARRASCO; PUERTAS, 2017; WALKLEY et al., 2016).

Regarding activators, sodium and potassium silicates and hydroxides are the most used (ADESANYA et al., 2021; DAVIDOVITS, 2017). The synthesis with sodium solutions having lower cost, wide availability, and low viscosity (PROVIS; BERNAL, 2014). The use of potassium activators favors zeolithization in geopolymer systems, but the crystallization rate is slower and rheology more favorable compared with their $\mathrm{NaOH}$ containing counterparts. The difference in ion size is likely to be a determining factor in reaction kinetics due to the tendency of the potassium cation to favor the formation of larger silicate oligomers (PROVIS; VAN DEVENTER, 2009).

Benavent, Frizon and Poulesquen (2016) compared geopolymers produced with sodium and potassium hydroxides in terms of the intrinsic porosity of the material and demonstrated that the use of the potassium activator leads to higher porosity and smaller pore sizes when the alkali silicate solution is prepared with the same silicate source. Different researchers studied the role of alkaline cations $\left(\mathrm{Na}^{+}\right.$and $\left.\mathrm{K}^{+}\right)$in the geopolymerization reaction and observed that the compressive strength of $\mathrm{Na}^{+}$systems was higher than that of systems using $\mathrm{K}^{+}$with the same $\mathrm{Si} / \mathrm{Al}$ ratio and alkali cation concentration (ABDUL RAHIM et al., 2015; ZHANG et al., 2017; SORE et al., 2020). However, results of Esparham, Moradikhou and Avanaki, (2020) showed that using $\mathrm{NaOH}$ provided greater 3- and 7- day compressive strengths and using $\mathrm{KOH}$ resulted in higher 28-day compressive strength. According to El Alouani et al. (2020) the fire resistance study revealed that the geopolymer binders induced by $\mathrm{KOH}$ are stable up to $600{ }^{\circ} \mathrm{C}$. Hosan, Haque and Shaikh, (2016) show that the geopolymer synthesized with potassium-based activators is more stable at elevated temperatures than its sodium-based counterparts in terms of higher residual compressive strengths, lower mass loss, lower volumetric shrinkage and lower cracking damage. Results obtained by Novais et al. (2016) and Si et al. (2020) using metakaolin and glass waste activated with $\mathrm{NaOH}$ showed that the incorporation of about $11 \%$ of the glass waste increased the compressive strength, while larger amounts showed the opposite result compared with the metakaolin-based geopolymer.

148 Alvarenga, C. do B. C. S.; Sales, R. do B. C.; Caldas, R. B.; Cetlin, P. R.; Aguilar, M. T. P. 
It is observed that there are still inconclusive points about the use of activators. Thus, focusing on the geopolymerization reaction, this study evaluates the efficiency of alkaline activation of metakaolin using Potassium Hydroxide and Potassium Silicate solution with and without partial replacement of $12.5 \%$ of the precursor weight by microparticles of glass waste, using room temperature and thermal curing. These wastes come from the grinding of cut and drilling leftovers which are discarded in landfills, constituting an environmental liability. Thus, it is expected to contribute to the environment and knowledge, associating the use of glass waste with the $\mathrm{KOH}$ activator and cure at room temperature.

\section{Materials and methods}

Geopolymers were synthesized using the following precursors: commercial metakaolin with a high degree of purity; microparticles of amber soda-lime glass obtained from the breakage of larger particles and/or from cuttings from the glass industry. The chemical composition and physical properties of metakaolin and glass waste are shown in Table 1.

In metakaolin the molar ratio is 2.3 . To obtain a polysialate-syloxo structure, a ratio of 3.3 to 4.5 would be required (KHALE; CHAUDHARY, 2007). Thus, it was necessary to use an alternative source of silica. In this study we opted for potassium silicate. Although rich in silica, glass waste has a $\mathrm{SiO}_{2} / \mathrm{Al}_{2} \mathrm{O}_{3}$ molar ratio of 151.0, which indicates that its activation would not lead to the formation of aluminum tetrahedra, delaying curing time (CYR; IDIR; POINOT, 2012). For this reason, we chose to utilize it together with metakaolin.

The new precursor proposed in this research, consisting of $12.5 \%$ glass in place of metakaolin, would have a molar ratio of 2.7, therefore higher than that of metakaolin. This notwithstanding, it would still require the association of silicate with the activator. Glass waste incorporation into the precursor increases $\mathrm{CaO}$ content, which in metakaolin is $0.1 \%$. The metakaolin particles have a medium size and specific surface larger than the glass waste ones, indicating greater surface roughness and, consequently, greater reactivity of these materials.

Potassium hydroxide and silicate were used for activation. High purity potassium hydroxide (86.1\%) and deionized water were used to prepare the $10 \mathrm{~mol} \mathrm{KOH}$ activator solution. Potassium Silicate solution (weight percentage: $12.8 \% \mathrm{~K}_{2} \mathrm{O}, 27.4 \% \mathrm{SiO}_{2}$, and $59.8 \% \mathrm{H}_{2} \mathrm{O}$ ) was also used as activator and as an additional source of silica.

The structure and phases present of precursors were evaluated by X-ray diffraction (XRD) and spectroscopy in the Infrared region with Fourier transform (FTIR) and nuclear magnetic resonance (NMR) of ${ }^{29} \mathrm{Si}$ and ${ }^{27} \mathrm{Al}$. For XRD, a Rigaku Geigerflex D/max-Series diffractometer, with $\mathrm{CuK} \alpha$ radiation, $10-80^{\circ}, 0.02^{\circ} 2 \theta$ step-scan, and $10 \mathrm{~s} /$ step were used. FTIR was performed on Bruker Tensor 27 equipment, with Golden gate ATR accessory, $4 \mathrm{~cm}^{-1}$ resolution, 256 scans, in the absorbency mode. Moreover, Bruker Ascend $700 \mathrm{MHz}$ solid-state NMR equipment with 16.4 Tesla field allowed the observation of ${ }^{27} \mathrm{Al}$ at $139.09 \mathrm{MHz}$ by single pulse analysis with magic-angle rotation in a $4 \mathrm{~mm}$ rotor system at $14.0 \mathrm{kHz}, 0.5 \mathrm{~s}$ repetition time, and 0.28 $\mu$ s pulse. The ${ }^{29} \mathrm{Si}$ observation tests were performed on Bruker 400 UltraShield equipment, with 9.4 Tesla field and $79.49 \mathrm{MHz}$ frequency, using single pulse analysis with angle rotation in a $7 \mathrm{~mm}$ rotor system at 5 $\mathrm{kHz}, 60 \mathrm{~s}$ repetition time, and $2.11 \mu$ s pulse.

Table 1 - Chemical composition and physical properties of metakaolin and glass waste

\begin{tabular}{|c|c|c|c|c|c|c|c|c|c|c|c|}
\hline \multicolumn{12}{|c|}{ Chemical composition (\%) } \\
\hline & $\mathrm{SiO}_{2}$ & $\mathrm{Al}_{2} \mathrm{O}_{3}$ & $\mathrm{CaO}$ & $\mathrm{K}_{2} \mathrm{O}$ & $\mathrm{Fe}_{2} \mathrm{O}_{3}$ & $\mathrm{TiO}_{2}$ & $\mathrm{MgO}$ & $\mathrm{Na}_{2} \mathrm{O}$ & $\mathrm{SO}_{3}$ & Other & LOI* \\
\hline Metakaolin & 51.3 & 38.0 & 0.1 & 2.8 & 2.6 & 1.6 & 0.9 & 0.1 & 0.04 & 2.6 & 2.2 \\
\hline Glass waste & 72.9 & 0.8 & 9.2 & 0.02 & 0.7 & - & 3.6 & 6.0 & 0.3 & 6.6 & 0.4 \\
\hline & & & & \multicolumn{3}{|c|}{ Metakaolin } & \multicolumn{2}{|c|}{ Glass waste } & & & \\
\hline \multicolumn{4}{|c|}{$\mathrm{SiO}_{2} / \mathrm{Al}_{2} \mathrm{O}_{3}$ Molar Ratio } & \multicolumn{3}{|c|}{2.3} & \multicolumn{2}{|c|}{151.0} & - & - & - \\
\hline \multicolumn{4}{|c|}{ Average particle size $\mathrm{d}_{50}(\mu \mathrm{m})$} & \multicolumn{3}{|c|}{11.8} & \multicolumn{2}{|c|}{7.6} & - & - & - \\
\hline \multicolumn{4}{|c|}{ Maximum particle size $d_{90}(\mu \mathrm{m})$} & \multicolumn{3}{|c|}{36,0} & \multicolumn{2}{|c|}{37.8} & - & - & - \\
\hline \multicolumn{4}{|c|}{ Gas adsorption BET $\left(\mathrm{m}^{2} / \mathrm{g}\right)$} & \multicolumn{3}{|c|}{14.5} & \multicolumn{2}{|c|}{3.0} & - & - & - \\
\hline
\end{tabular}

Note: *loss of ignition. 
Based on the results of Novais et al. (2016), the samples were prepared with $100 \%$ metakaolin (Geo-Ref.) and by replacing $12.5 \%$ of this weight by glass waste (Geo-Glass). Table 2 presents the proportions and molar ratios of the mixtures with and without glass waste (Geo-Ref and Geo-Glass, respectively), calculated based on the chemical composition of the precursor materials and activating solution. Increasing the $\mathrm{SiO}_{2} / \mathrm{Al}_{2} \mathrm{O}_{3}$ molar ratio was also considered to promote positive effects on compressive strength; however, there is a threshold from which this strength decreases (NOVAIS et al., 2016). Thus, using potassium silicate in the preparation of geopolymers increased the molar ratio of the mixtures from 2.3 to 3.3 in reference geopolymers, and from 2.7 to 3.9 in glass waste geopolymers, both within the limits (3.3 to 4.5) recommended in the literature.

In determining activator content (Table 2), the following limits were used for the best performance of geopolymers: $\mathrm{K}_{2} \mathrm{O} / \mathrm{Al}_{2} \mathrm{O}_{3}(0.8-1.6) ; \mathrm{K}_{2} \mathrm{O} / \mathrm{SiO}_{2}(0.2-0.48) ; \mathrm{H}_{2} \mathrm{O} / \mathrm{K}_{2} \mathrm{O}$ (10.0-25.0) (KHALE; CHAUDHARY, 2007). Moreover, viscosity control included the analysis of the $\mathrm{H}_{2} \mathrm{O} / \mathrm{K}_{2} \mathrm{O}$ molar ratio, since the presence of water is important for ion mobility during dissolution, but its excess reduces the alkalinity of the solution and decreases the reaction rate.

Potassium hydroxide and silicate were used in a combination. The preparation of geopolymer pastes first involved homogenizing the potassium silicate and $\mathrm{KOH}$ solution in a mechanical mixer for about 2 min., obtaining an alkaline activator solution. The activator solution was added to previously oven dried metakaolin and/or metakaolin/glass. After mechanical homogenization at room temperature for $7 \mathrm{~min}$., the mixtures were subjected to mechanical vibration for $5 \mathrm{~min}$. for removal of air bubbles.

The activated material was then poured into PVC (DEUTSCHES..., 2012) cylindrical molds previously greased with liquid Vaseline to facilitate demolding. The various PVC molds containing the geopolymer were placed inside a silicone mold for stability and were again vibrated for about $10 \mathrm{~min}$. to remove air bubbles, formed during the preparation of the activators, and to ease mold filling. To ensure the flat and even geometry of the exposed surfaces, all specimens were placed between two plumb leveled glass plates and wrapped in plastic film. Part of the samples was cured at room temperature (Geo-Ref-RO and Geo-GlassRO) and part thermally cured at $40{ }^{\circ} \mathrm{C}$ for 24 hours (Geo-Ref-TH and Geo-Glass-TH). The samples were then demolded and kept at room temperature, being wrapped in plastic for another 27 days.

The occurrence of geopolymerization was analyzed after 28 days of curing by XRD, FTIR, and NMR of the ${ }^{29} \mathrm{Si}$ and ${ }^{27} \mathrm{Al}$ at the same conditions used to characterize the precursors.

The specific mass and compressive strength of the synthesized pastes were also evaluated after $24 \mathrm{~h}, 7$ days, and 28 days of cure. Three specimens of each mixture were tested for each age. After demolding, specimens had their mass and dimensions measured with a precision scale (Bel Engineering, Piracicaba, Brazil) and an IP65 caliper (Mitutoyo, Aurora, IL, USA). Based on this information, specific masses were determined. In the compressive strength test, an Instron 5582 universal machine with a capacity of $100 \mathrm{kN}$ was used. The compression rate used in the test was $0.01 \mathrm{~mm} / \mathrm{s}$ and load application occurred until rupture.

Table 2 - Mixture/activator composition and atomic/molar ratios

\begin{tabular}{l|l|c|c}
\hline & \multicolumn{1}{|c|}{ Identification } & Geo-Ref-10 mol & Geo-Glass-10 mol \\
\hline \multirow{4}{*}{ Molar ratios } & $\mathrm{SiO}_{2} / \mathrm{Al}_{2} \mathrm{O}_{3}$ (no silicate) & 2.3 & 2.7 \\
& $\mathrm{SiO}_{2} / \mathrm{Al}_{2} \mathrm{O}_{3}$ & 3.3 & 3.9 \\
& $\mathrm{~K}_{2} \mathrm{O} / \mathrm{Al}_{2} \mathrm{O}_{3}$ & 1.0 & 1.1 \\
& $\mathrm{~K}_{2} \mathrm{O} / \mathrm{SiO}_{2}$ & 0.3 & 0.3 \\
& $\mathrm{H}_{2} \mathrm{O} / \mathrm{K}_{2} \mathrm{O}$ & 14.2 & 14.2 \\
\hline \multirow{5}{*}{ Mixture composition $(\%)$} & $\mathrm{Metakaolin}$ & 41.2 & 36.0 \\
& $\mathrm{Glass}$ waste & 0.0 & 5.1 \\
& $\mathrm{~K}_{2} \mathrm{SiO}$ & 34.2 & 34.2 \\
& $\mathrm{KOH}(10 \mathrm{~mol} / \mathrm{l})$ & 24.7 & 24.7 \\
\hline
\end{tabular}

150 Alvarenga, C. do B. C. S.; Sales, R. do B. C.; Caldas, R. B.; Cetlin, P. R.; Aguilar, M. T. P. 


\section{Results and discussions \\ Characterization of precursors}

Based on the diffractograms in Figure 1, metakaolin shows the presence of the following crystalline phases: kaolinite, quartz, muscovite, and anatase. The presence of a curved region (halo) formed by the deviation from the baseline at $2 \theta=18^{\circ}$ to $30^{\circ}$ can be attributed to amorphous aluminosilicates (DUXSON et al., 2007a; PROVIS; VAN DEVENTER, 2009). The presence of kaolinite and other crystalline phases is an indication of incomplete calcination of kaolinite which negatively influences geopolymerization (BENEZET; BENHASSAINE, 2009; MENEZES et al., 2018). The diffuse spectrum observed throughout the glass waste diffractogram, as well as the halo present at $2 \theta=15^{\circ}$ to $35^{\circ}$, indicate that the material is amorphous (TORRES-CARRASCO, 2015). Considering that predominantly amorphous materials are more reactive than crystalline ones (SCRIVENER; NONAT, 2011), it can be inferred that the use of glass waste as a partial substitute for metakaolin would facilitate geopolymer synthesis.

The results obtained by Fourier transform infrared (FTIR) spectroscopy for metakaolin and glass waste are shown in Figure 2. The metakaolin spectrum shows vibrations at $1006 \mathrm{~cm}^{-1}$ that were related to $\mathrm{Si}-\mathrm{O}-\mathrm{Al}$ stretching vibrations. Lower values in the range from 1000 to $1100 \mathrm{~cm}^{-1}$ would correspond to greater incorporation of aluminum into the aluminosilicate structure. Moreover, Si-O-M (M: alkali metal) stretching vibrations near $910 \mathrm{~cm}^{-1}$ were also detected.

Figure 1 - X-ray diffractogram of metakaolin and glass waste

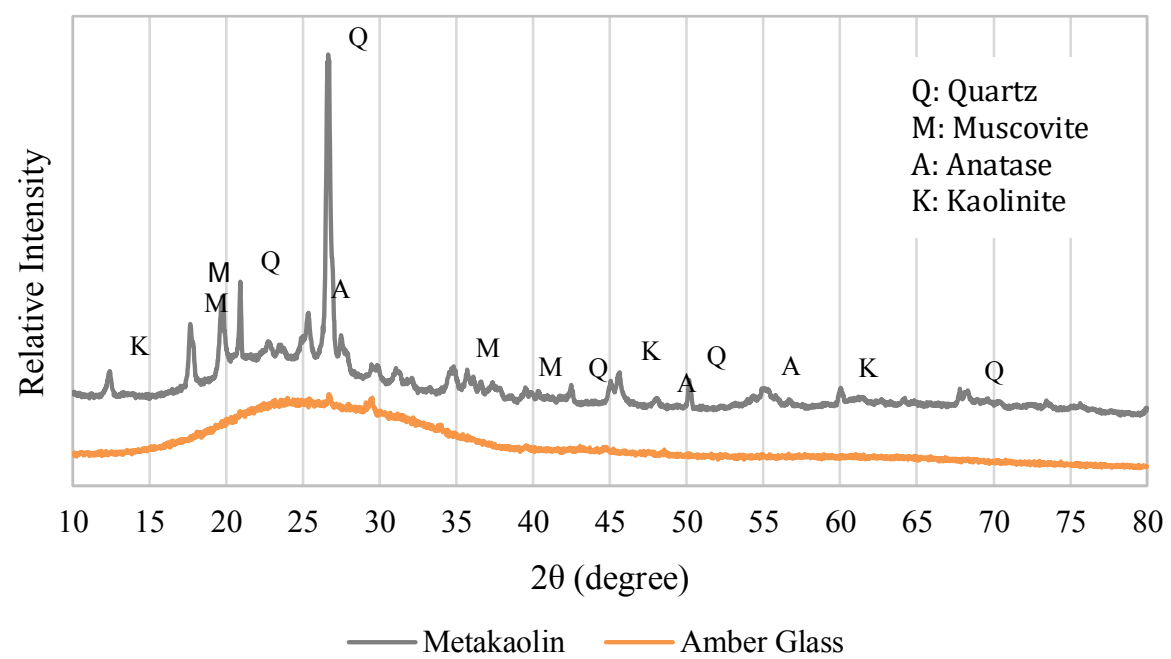

Figure 2 - Infrared Spectroscopy results for metakaolin and glass waste

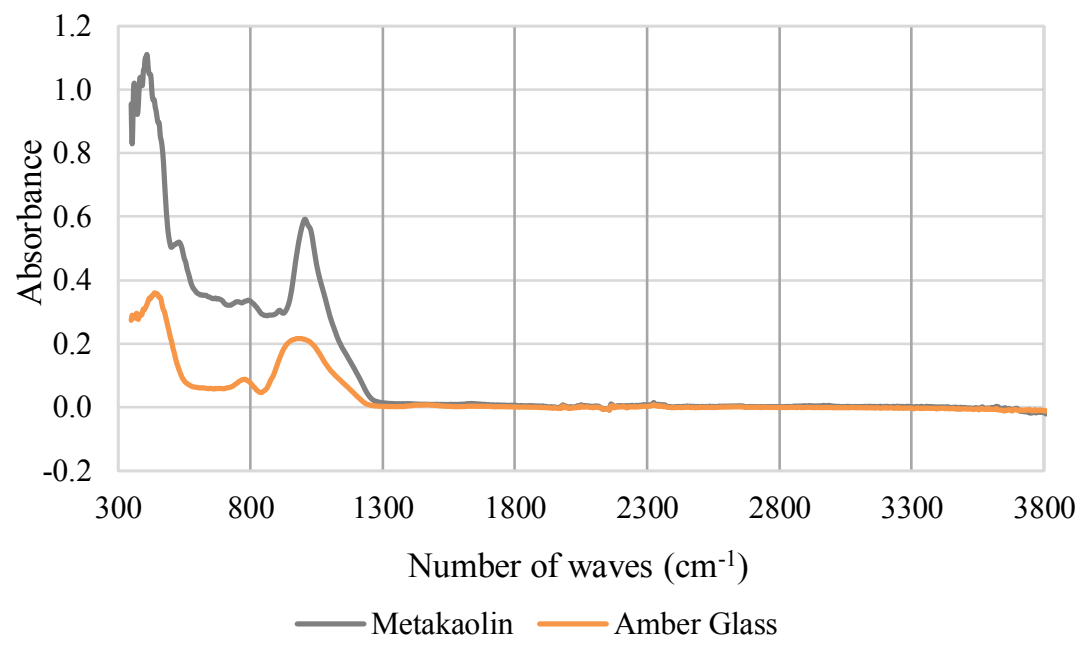


Four peaks of lower intensity were detected in the 791, 754, 678, and $529 \mathrm{~cm}^{-1}$ bands. Although not fully within the ranges described by Zhang et al. (2012), the following relationships can be inferred from Table 3: symmetric Si-O-Si stretching vibrations in quartz at $791 \mathrm{~cm}^{-1}$; symmetric Al-O-Al stretching vibrations in tetrahedral coordination at 754 and $678 \mathrm{~cm}^{-1}$; symmetric Al-O-Si stretching vibrations at $529 \mathrm{~cm}^{-1}$. In the literature, the lowest vibrations cited are near $450 \mathrm{~cm}^{-1}$, corresponding to the bending of Si-O-Si bonds, and could be related to the vibrations detected at $408 \mathrm{~cm}^{-1}$. Between $1300 \mathrm{~cm}^{-1}$ and $3800 \mathrm{~cm}^{-1}$, no significant disturbance is observed, indicating the absence of hydration water $\left(3450\right.$ and $\left.1650 \mathrm{~cm}^{-1}\right)$ in the precursor materials. Thus, the metakaolin spectrum indicates the existence of a continuous and random network of amorphous aluminosilicates favorable to geopolymerization. The glass waste result shows three peaks around 992, 778, and $438 \mathrm{~cm}^{-1}$, which refer to the $\mathrm{SiO}_{2}$ network. Similar results were found by Sales (2014). The $992 \mathrm{~cm}^{-1}$ band is probably related to asymmetric stretching of Si-O-Si bonds, typical of amorphous glass structures. Vibrations at $778 \mathrm{~cm}^{-1}$, related to symmetric Si-O-Si stretching, and at $438 \mathrm{~cm}^{-1}$, attributed to O$\mathrm{Si}-\mathrm{O}$ angular deformation, were detected. These results would confirm glass waste amorphousness.

The ${ }^{27} \mathrm{Al}$ spectrum obtained by nuclear magnetic resonance for metakaolin is shown in Figure 3 . According to Duxson (2006), aluminum in the tetrahedral $\left(\mathrm{AlO}_{4}\right)$, pentahedral $\left(\mathrm{AlO}_{5}\right)$, and hexahedral $\left(\mathrm{AlO}_{6}\right)$ coordination are highly reactive and during geopolymerization reaction they are converted into tetrahedral sites associated with an alkali cation to maintain electron neutrality. The obtained spectrum showed the presence of signals at $55 \mathrm{ppm}$ for tetrahedral coordination, at $30 \mathrm{ppm}$ for pentahedral coordination, and at 5 ppm for hexahedral coordination. According to the same author, approximately equal proportions of aluminum are found in the mentioned coordination frameworks for metakaolin. In the present study, however, aluminum in hexahedral coordination is in greater proportion, indicating the presence of kaolinite, which could decrease the extent of geopolymerization (BENEZET; BENHASSAINE, 2009; MENEZES et al., 2018).

Table 3 - Assignment of absorption bands obtained by infrared spectroscopy for metakaolin and glass waste

\begin{tabular}{c|c|c|c}
\hline $\mathbf{c m}^{-1}$ & Metakaolin & $\mathbf{c m}^{-1}$ & Glass Waste \\
\hline 1006 & Si-O-Al (stretching) & 992 & Si-O-Si (stretching) \\
901 & Si-O-M (stretching) & 778 & Si-O-Si (stretching) \\
791 & Si-O-Si (stretching) & 438 & O-Si-O (bending) \\
$754 / 768$ & Al-O-Al (stretching) & & \\
529 & Al-O-Si (stretching) & & \\
408 & Si-O-Si (bending) & & \\
\hline
\end{tabular}

Figure 3 - Nuclear magnetic resonance of metakaolin $\left({ }^{27} \mathrm{Al}\right.$ solid-state)

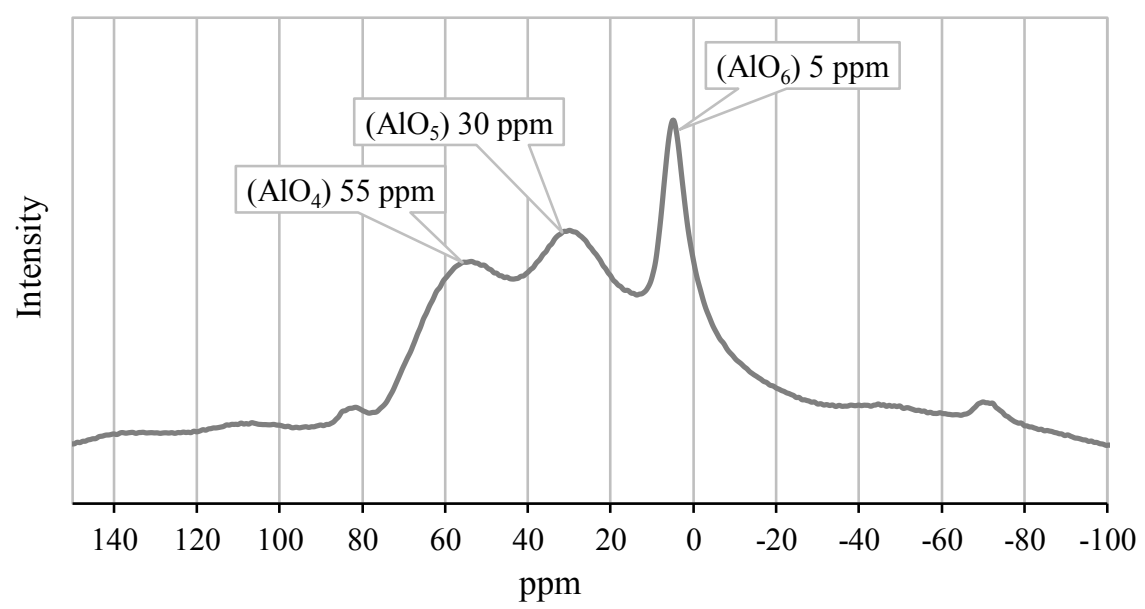

152 Alvarenga, C. do B. C. S.; Sales, R. do B. C.; Caldas, R. B.; Cetlin, P. R.; Aguilar, M. T. P. 
The ${ }^{29} \mathrm{Si}$ spectrum obtained by NMR for metakaolin is shown in Figure 4. According to Lecomte et al. (2003) and Duxson (2006) the signal near $-92 \mathrm{ppm}$ is attributed to kaolin silicates and represents a $\mathrm{Si}$ nucleus bonded to 3 other silicon atoms by covalent bonding $\left(\mathrm{Q}^{3}\right)$. After calcination, the same authors argue that crystallinity is expected to be lower, with the material showing a single peak at approximately -107 ppm, which can be attributed to a Si nucleus bonded to 4 other silicon atoms $\left(\mathrm{Q}^{4}\right)$. According to Valcke et al . (2015) this resonance would be close to $-100 \mathrm{ppm}$. Rowles et al. (2007) describe a broad resonance for metakaolin at $104.8 \mathrm{ppm}\left(\mathrm{Q}^{4}(1 \mathrm{Al})-\mathrm{Q}^{4}(0 \mathrm{Al})\right)$, which would be indicative of highly disordered structural networks. In this study, metakaolin showed signals around $-107 \mathrm{ppm}$ and $-9 \mathrm{ppm}$, reinforcing the results of $\mathrm{x}$-ray diffraction and infrared spectroscopy, which showed that the material was not properly calcined. The signal width indicates that this is an amorphous structure formed on kaolinite calcination.

\section{Characterization of geopolymers}

\section{XRD and FTIR analysis}

The XRD patterns of geopolymers after curing for 28 days are shown in Figure 5, along with that of metakaolin. The position of the diffraction peaks at $2 \theta=26^{\circ}$ in the geopolymers coincides with those of metakaolin, indicating the presence of quartz, i.e., unreacted material in the geopolymers. There is a halo in all geopolymer samples, corresponding to the existence of an amorphous phase, between $2 \theta=20^{\circ}$ to $35^{\circ}$, being displaced in relation to metakaolin $\left(2 \theta=18^{\circ}\right.$ to $\left.30^{\circ}\right)$. This change has been associated with the formation of new amorphous phases, being indicative of geopolymeric reaction (DUXSON et al., 2007b; PROVIS; VAN DEVENTER, 2009). The position of the diffraction peak of geopolymer samples with and without glass waste coincides with the metakaolin peak. This occurs probably because of the low waste glass content used.

Figure 4 - Nuclear magnetic resonance of metakaolin $\left({ }^{29} \mathrm{Si}\right.$ solid-state)

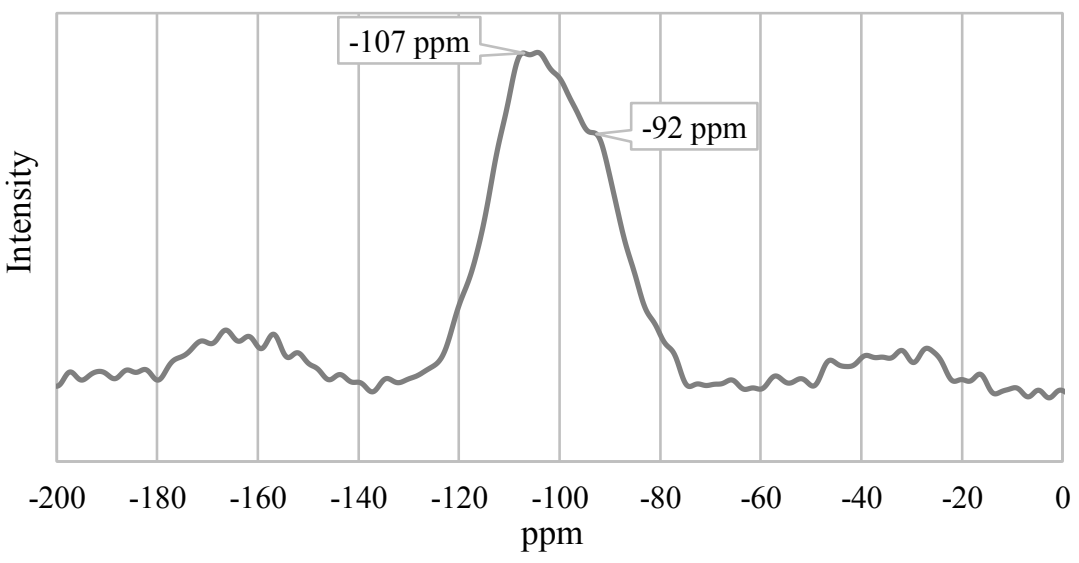

Figure 5 - X-ray diffractogram of geopolymers

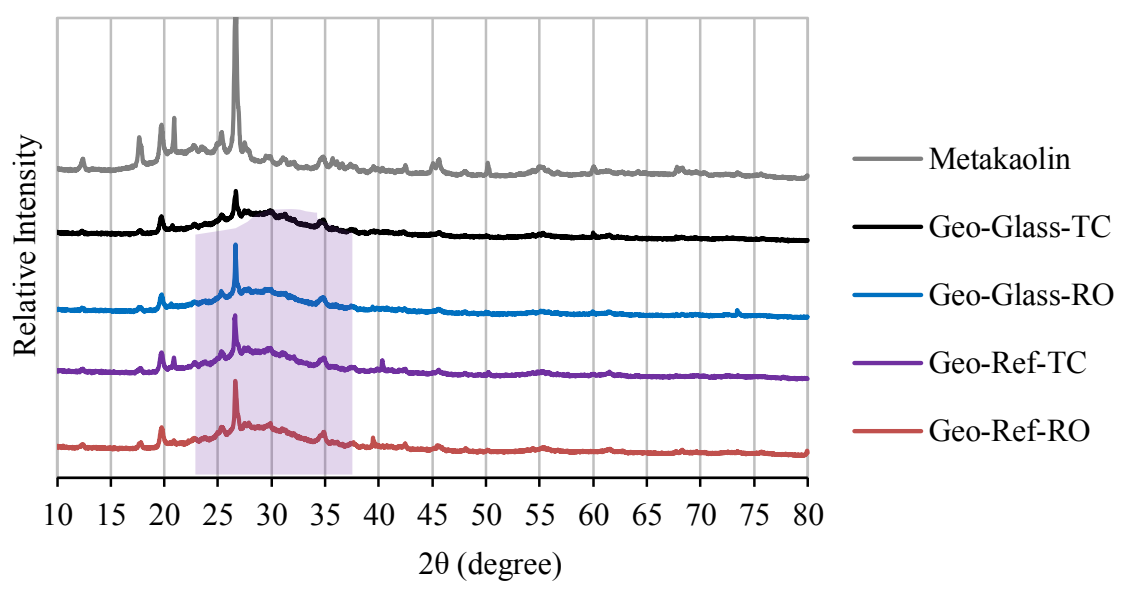


The spectra shown in Figure 6 were obtained by infrared spectroscopy for geopolymers cured for 28 days. There is no difference in the geopolymer spectra. However, there is a shift from the $1006 \mathrm{~cm}^{-1}$ band in metakaolin to $970 \mathrm{~cm}^{-1}$ in geopolymers. Valcke et al. (2015) describe that this shift to lower wavelengths in geopolymers occurs by the increased proportion of $\mathrm{Al}$ atoms in the tetrahedral position. This result indicates that geopolymerization reactions form a larger number of Si-O-Al bonds in the aluminosilicate structure. The bands around 3450 and $1650 \mathrm{~cm}^{-1}$ observed in the activated mixtures correspond to water resulting from geopolymerization.

\section{Solid-state NMR analysis}

The ${ }^{27} \mathrm{Al}$ spectra obtained by nuclear magnetic resonance of geopolymers and metakaolin are shown in Figure 7. Geopolymerization was notable in the geopolymer pastes produced, since a significant peak was observed in the range that characterizes tetrahedral coordination $(55 \mathrm{ppm})$ and no pentahedral peaks $(30$ ppm) were identified. It is possible to identify peaks at approximately $5 \mathrm{ppm}$ that would correspond to aluminum in hexahedral coordination, indicating the presence of uncalcined kaolinite, also identified in Xray diffraction. This spectrum is similar to that observed in the studies by Duxson (2006) and Rowles et al. (2007), which associate it to geopolymerization and zeolite systems. No differences were observed regarding the presence of glass waste and curing type, indicating the contribution of waste to geopolymerization.

The ${ }^{29} \mathrm{Si}$ spectra obtained by nuclear magnetic resonance of geopolymers and metakaolin are shown in Figure 7. The signal near $-92 \mathrm{ppm}$ is shown to be permanent in all geopolymers, which may be related to kaolin silicates (LECOMTE et al., 2003). However, widening of this signal indicates the formation of a new, probably amorphous $\mathrm{Q}^{3}$ structure. The strong signal reduction at $-107 \mathrm{ppm}$ would indicate that $\mathrm{Q}^{4}$ units were consumed in the geopolymeric reaction (DUXSON, 2006). The peak intensity of thermally-cured samples is attenuated compared to room temperature cured samples, and the presence of glass waste does not interfere with the spectrum.

\section{Apparent specific mass}

The influence of curing type and glass waste incorporation on the apparent specific mass of geopolymers can be seen in Figure 8, where the average values as well as the amplitude of the measurements are presented. In all samples, the apparent specific mass decreased during curing, which can be attributed to the release of water that occurs during geopolymerization (NOVAIS et al., 2016; PIMRAKSA et al., 2011). The glass waste geopolymer cured at room temperature showed higher density at all three ages and, therefore, lower porosity. Considering that glass waste and metakaolin have close specific masses $\left(2.5\right.$ and $2.6 \mathrm{~g} / \mathrm{cm}^{3}$, respectively), it was expected that the reference geopolymer had the largest specific mass due to its higher surface roughness. This would make it more reactive and, consequently, provide it with a denser and more resistant structure (NAZARI; BAGHERI; RIAHI, 2011). This fact did not occur probably due to the higher $\mathrm{CaO}$ content present in the glass waste sample. According to Khale and Chaudhary (2007), the formation of an amorphous and/or semicrystalline $\mathrm{Ca}-\mathrm{Al}-\mathrm{Si}$ structure reduces geopolymer porosity. The density of thermally-cured geopolymers is lower than that of those exposed to room temperature in the three analyzed ages (24 h, 7 days, and 28 days). The temperature of $40{ }^{\circ} \mathrm{C}$ may have induced an increase in the geopolymerization reaction rate, which consequently contributed to the increase of the water release rate. The thermally-cured glass waste sample had a higher density than the heat-treated reference, a trend similar to that observed at room temperature curing, probably due to the influence of calcium on the structure. The apparent specific mass obtained after $24 \mathrm{~h}$ of thermal curing for the $\mathrm{KOH}$-activated thermal sample is about the same as that obtained by Novais et al. (2016) in similar material activated with $\mathrm{NaOH}$. At 28 days, however, the apparent specific mass of the $\mathrm{KOH}$-activated glass waste thermal sample is superior.

\section{Compressive strength}

The influence of curing type and glass waste incorporation on compressive strength can be seen in Figure 9, where the average values and the amplitude of the measurements are presented. For all situations; compressive strengths above $26 \mathrm{MPa}$ are obtained within $24 \mathrm{~h}$.

Glass waste incorporation: the incorporation of $12.5 \%$ glass waste increased mechanical strength at 28 days from $25 \mathrm{MPa}$ to $36 \mathrm{MPa}$ for room temperature curing and from $27 \mathrm{MPa}$ to $37 \mathrm{MPa}$ for thermal curing. The replacement of metakaolin by glass waste increased the initial $\mathrm{SiO}_{2} / \mathrm{Al}_{2} \mathrm{O}_{3}$ ratio with positive effects on strength. This occurs because Si-O-Si bonds are stronger than Si-O-Al and Al-O-Al bonds in geopolymers (BOBIRICĂ et al., 2015). Ozer and Soyer (2015) observed that compressive strength systematically

154 Alvarenga, C. do B. C. S.; Sales, R. do B. C.; Caldas, R. B.; Cetlin, P. R.; Aguilar, M. T. P. 
increased with increasing Si/Al molar ratio. Furthermore, using $10 \mathrm{~mol} \mathrm{NaOH}$, metakaolin, and fluorescent lamp glass waste, Novais et al. (2016) also observed an increase in compressive strength from $11.5 \mathrm{MPa}$ to 15.5 MPa. In turn, Hao et al. (2013) reported that, after 28 days of curing, samples containing $10 \%$ of solar panel waste glass had compressive strengths of 12.5, 39.0, 63.3, and 66.7 MPa with solid-liquid ratio of 0.4 , $0.6,0.8$, and 1.0 , respectively.

Figure 6 - Results of the Infrared Spectroscopy of geopolymers

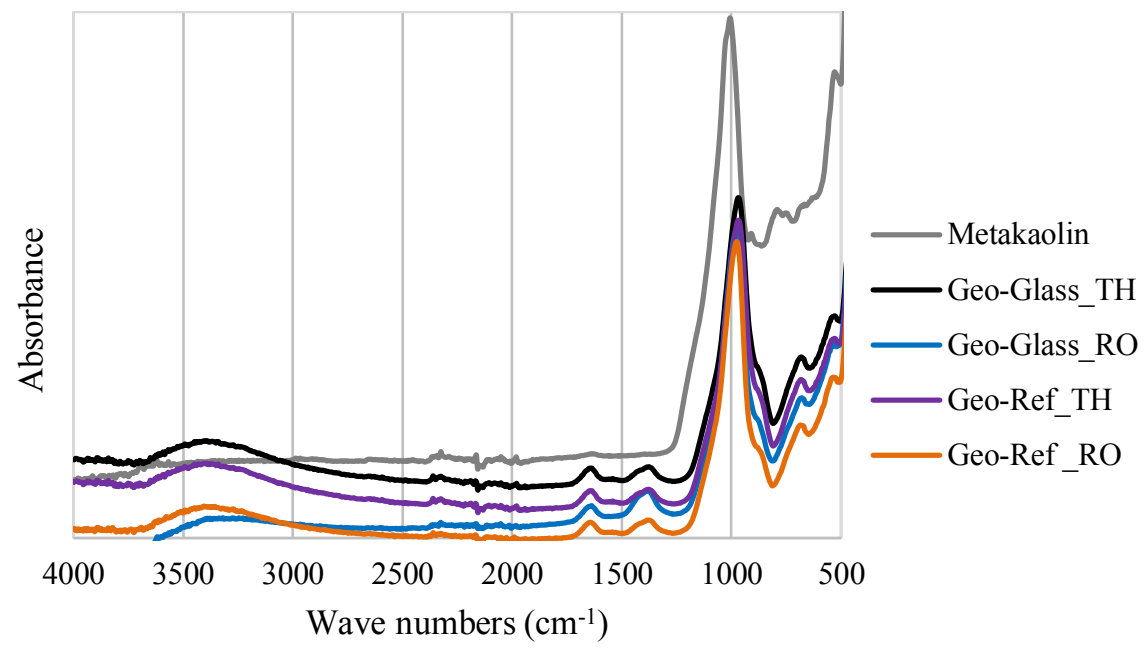

Figure 7 - Nuclear magnetic resonance of geopolymers

${ }^{27} \mathrm{Al}$ solid-state

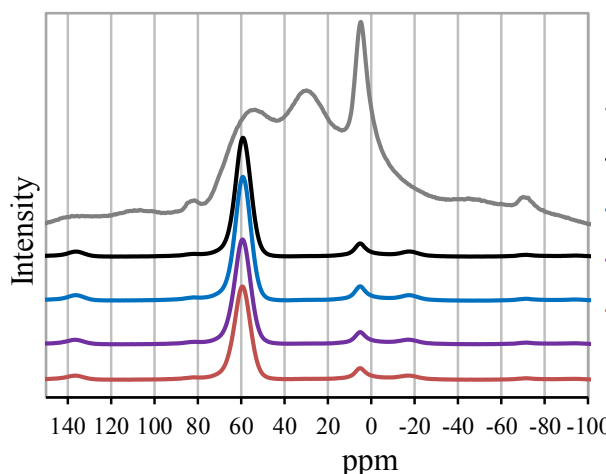

${ }^{29} \mathrm{Si}$ solid-state

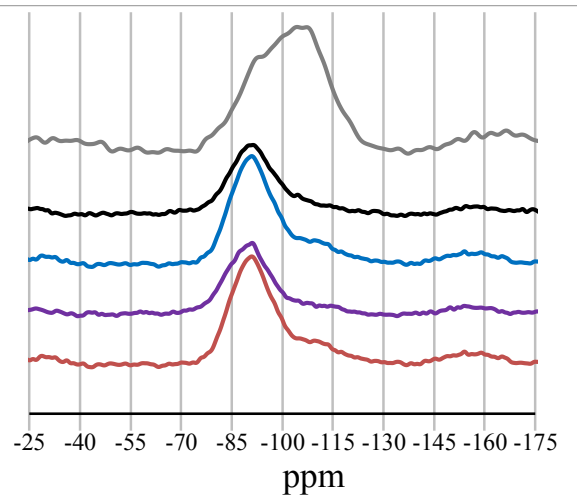

Figure 8 - Apparent specific mass of geopolymers at $24 \mathrm{~h}, 7$ days, and 28 days

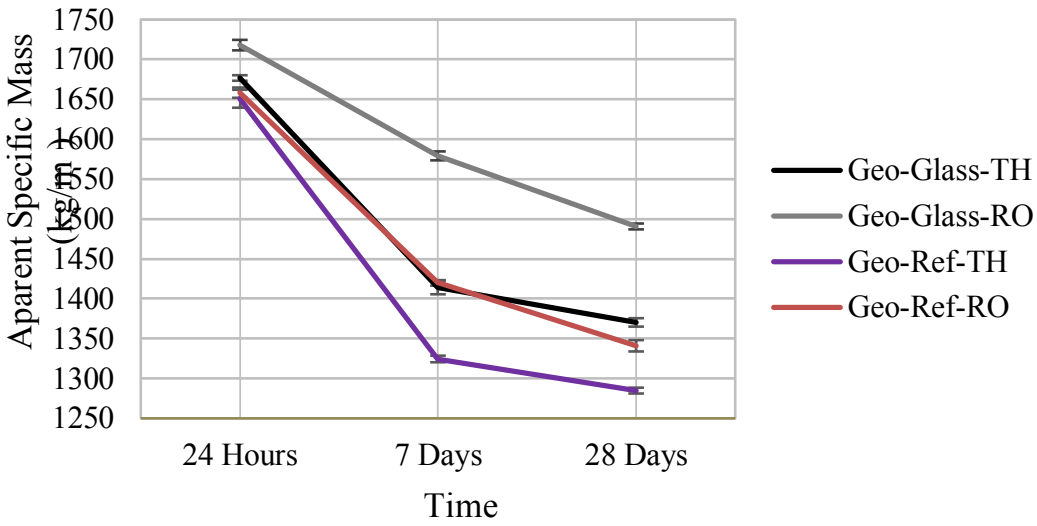


Figure 9 - Compressive strength of geopolymers at 24h, 7 days, and 28 days

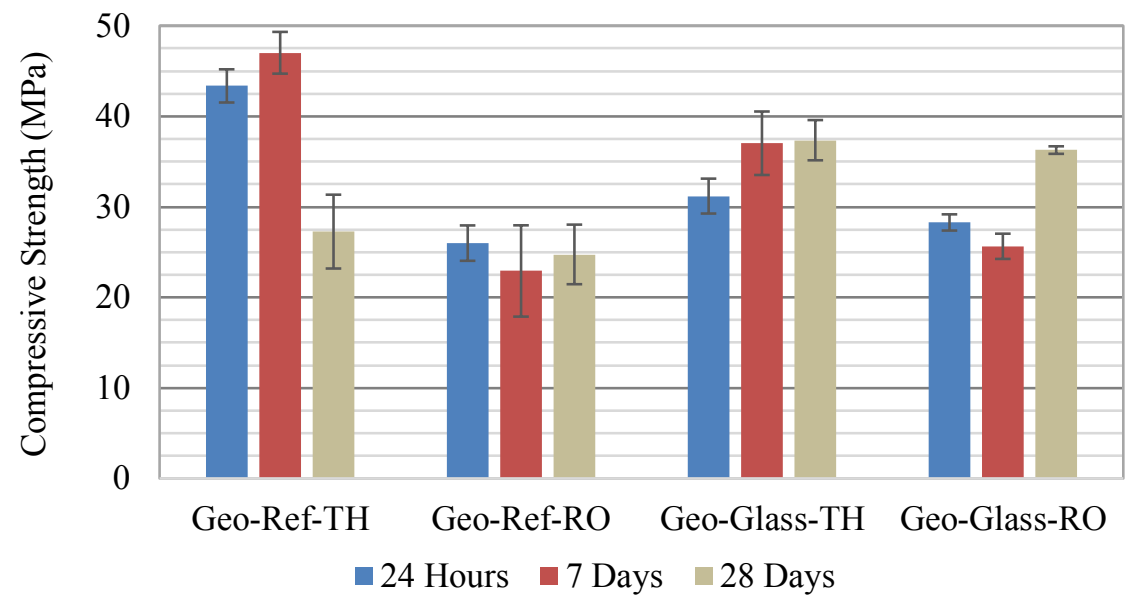

Thermally-cured glass waste-added samples achieved compressive strengths of $31 \mathrm{MPa}$ in the first 24 hours, with a slight elevation at 7 days (37 MPa, remaining until 28 days). Glass waste incorporation increased the presence of $\mathrm{CaO}$ in the geopolymer matrix, which favored the formation of an amorphous and/or semicrystalline $\mathrm{Ca}-\mathrm{Al}-\mathrm{Si}$ structure, reducing porosity and increasing mechanical resistance (GARCIALODEIRO et al., 2011; KHALE; CHAUDHARY, 2007; XU et al., 2014). Room temperature cured glass waste-added samples reached compressive strengths of $28 \mathrm{MPa}$ in the first $24 \mathrm{hs}$, with a slight decrease at 7 days (26 MPa, which increased to $36 \mathrm{MPa}$ at 28 days).

When cured at room temperature, glass waste does not appear to affect strength at an early age. Substitution with glass waste possibly reduced the release rates of silicon and aluminum ions due to the lower rate of glass waste dissolution compared to metakaolin, which would affect strength development (HAO et al., 2013).

Influence of curing type: for reference geopolymers wrapped in plastic film, without glass waste addition, curing at $40{ }^{\circ} \mathrm{C}$ for 24 hours favored strength development in the early ages (43 MPa/24 hours; $47 \mathrm{MPa} / 7$ days). However, at 28 days, this decreased significantly to $27 \mathrm{MPa}$. In the case of $\mathrm{NaOH}$ activator, the literature associates this decrease in compressive strength at 28 days with precipitation of silicates and aluminates due to excess $\mathrm{Na}^{+}$ions in the mixture. These destroy $\mathrm{Si}-\mathrm{O}-\mathrm{Si}$ stronger bonds, where one silicon atom is bonded to four other silicon atoms by covalent bonds $\left(\mathrm{Q}^{4}\right)$, forming $\mathrm{Si}-\mathrm{O}-\mathrm{Na}$ species, which are characterized as NBO (Nonbridging Oxygens) and show $\mathrm{Q}^{2}$ (Si nucleus bonded to two other atoms) NMR coupling (ONORATO et al., 1985; ZIRL; GAROFALINI, 1992). Another possible explanation for this reduction in mechanical strength would be the formation of fissures caused by shrinkage (GUO; YANG, 2020; SI et al., 2020). However, in the case of thermal curing, glass waste-added geopolymers showed no decrease in strength at 28 days.

In the reference samples cured at room temperature, strength reached $26 \mathrm{MPa}$ in 24 hours, decreasing to 23 $\mathrm{MPa}$ at 7 days, and with a slight increase at 28 days $(25 \mathrm{MPa})$. Samples at $40{ }^{\circ} \mathrm{C}$ reached higher resistance at 24 hours and at 7 days compared to the samples cured at room temperature, an indication that the temperature increase in thermal curing accelerated the geopolymerization reaction. Nevertheless, reference samples cured thermally and at room temperature reached practically the same compressive strengths at 28 days (27 and $25 \mathrm{MPa}$, respectively). In some situations, compressive strength increases with age while their density diminishes. This could be related to the formation of expansive products with high compressive strength.

\section{Conclusions}

This study evaluates the use of microparticles of glass waste in the replacement of $12.5 \%$ metakaolin weight for the production of $\mathrm{KOH} /$ Potassium silicate-activated geopolymers under room temperature and thermal curing. Replacing 12.5\% metakaolin weight with glass waste increased the compressive strength at 28 days for both curing types. Glass waste replacement increased the initial reactive $\mathrm{SiO}_{2} / \mathrm{Al}_{2} \mathrm{O}_{3}$ ratio with positive effects on compression strength, canceling a possible negative effect of the smaller specific surface of the glass on the reactivity of the precursors. It was also observed that glass waste incorporation increased the

156 Alvarenga, C. do B. C. S.; Sales, R. do B. C.; Caldas, R. B.; Cetlin, P. R.; Aguilar, M. T. P. 
density of room temperature cured samples. Furthermore, the presence of $\mathrm{CaO}$ probably contributed to the reduction of the geopolymer pores. This increase in density was not observed in thermal curing, possibly due to the high initial water release rate that would impair the calcium reaction in the structure. For metakaolinbased geopolymers, the curing type significantly affected strength development at early ages; however, at 28 days no significant differences were observed. Glass waste incorporation in thermal curing was beneficial for compressive strength at early ages; however, at 28 days the strengths in both curing types were similar. For samples of geopolymers with and without replacement of metakaolin with glass waste, $10 \mathrm{~mol} \mathrm{KOH}$ activation promoted compressive strengths above $26 \mathrm{MPa}$ at $24 \mathrm{~h}$, higher than the values found in the literature for $10 \mathrm{~mol} \mathrm{NaOH}$. This research shows that it is possible to reintroduce an environmental liability in the production process of geopolymer which has compressive strength compatible with Portland cement pastes for use in structural concretes.

\section{References}

ABDUL RAHIM, R. H. et al. Comparison of using $\mathrm{NaOH}$ and $\mathrm{KOH}$ activated fly ash-based geopolymer on the mechanical properties. Materials Science Forum, v. 803, p. 179-184, sep. 2015.

ABDULKAREEM, M. et al. Environmental and economic perspective of waste-derived activators on alkaliactivated mortars. Journal of Cleaner Production, v. 280, part 1, 2021.

ADESANYA, E. et al. Opportunities to improve sustainability of alkali-activated materials: a review of side-stream based activators. Journal of Cleaner Production, v. 286, 2021.

BENAVENT, V.; FRIZON, F.; POULESQUEN, A. Effect of composition and aging on the porous structure of metakaolin-based geopolymers. Journal of Applied Crystallography, v. 49, n. 6, p. 2116-2128, 2016.

BENEZET, J. C.; BENHASSAINE, A. Contribution of different granulometric populations to powder reactivity. Particuology, v. 7, n. 1, p. 39-44, 2009.

BERNAL, S. A.; PROVIS, J. L. Durability of alkali-activated materials: progress and perspectives. Journal of the American Ceramic Society, v. 97, n. 4, p. 997-1008, 2014.

BOBIRICĂ, C. et al. Influence of waste glass on the microstructure and strength of inorganic polymers. Ceramics International, v. 41, n. 10, p. 13638-13649, 2015.

CYR, M.; IDIR, R.; POINOT, T. Properties of inorganic polymer (geopolymer) mortars made of glass cullet. Journal of Materials Science, v. 47, n. 6, p. 2782-2797, 2012.

DAVIDOVITS, J. Geopolymers: ceramic-like inorganic polymers. Journal of Ceramic Science and Technology, v. 8, n. 3, p. 335-350, 2017.

DIMAS, D.; GIANNOPOULOU, I.; PANIAS, D. Polymerization in sodium silicate solutions: a fundamental process in geopolymerization technology. Journal of Materials Science, v. 44, n. 14, p. 3719$3730,2009$.

DEUTSCHES INSTITUT FÜR NORMUNG. EN 12390-1: european standards: testing hardened concrete: part 1: shape, dimensions and other requirements for specimens and moulds. Berlin, 2012.

DUXSON, P. The structure and thermal evolution of metakaolin geopolymers. Melbourne, 2006. Thesis - Faculty of Engineering, University of Melbourne, Melbourne, 2006.

DUXSON, P. et al. Geopolymer technology: the current state of the art. Journal of Materials Science, v. 42, n. 9, p. 2917-2933, 2007a.

DUXSON, P. et al. The role of inorganic polymer technology in the development of "green concrete". Cement and Concrete Research, v. 37, n. 12, p. 1590-1597, $2007 \mathrm{~b}$.

EL ALOUANI, M. et al. Influence of the nature and rate of alkaline activator on the physicochemical properties of fly ash-based geopolymers. Advances in Civil Engineering, v. 2020, art. 8880906, p. 1-13, 2020.

ESPARHAM; MORADIKHOU, A. B.; AVANAKI, M. J. Effect of various alkaline activator solutions on compressive strength of fly ash-based geopolymer concrete. Journal of Civil Engineering and Materials Application, v. 4, p. 115-123, apr. 2020.

FENG, D.; PROVIS, J. L.; VAN DEVENTER, J. S. J. Thermal activation of albite for the synthesis of onepart mix geopolymers. Journal of the American Ceramic Society, v. 95, n. 2, p. 565-572, 2012. 
GAO, K. et al. Effects $\mathrm{SiO} 2 / \mathrm{Na} 2 \mathrm{O}$ molar ratio on mechanical properties and the microstructure of nano$\mathrm{SiO} 2$ metakaolin-based geopolymers. Construction and Building Materials, v. 53, p. 503-510, 2014.

GARCIA-LODEIRO, I. et al. Compatibility studies between N-A-S-H and C-A-S-H gels: study in the ternary diagram Na2O-CaO-Al2O3-SiO 2-H2O. Cement and Concrete Research, v. 41, n. 9, p. 923-931, 2011.

GUO, X.; YANG, J. Intrinsic properties and micro-crack characteristics of ultra-high toughness fly ash/steel slag based geopolymer. Construction and Building Materials, v. 230, 2020.

HABERT, G.; D'ESPINOSE DE LACAILLERIE, J. B.; ROUSSEL, N. An environmental evaluation of geopolymer based concrete production: Reviewing current research trends. Journal of Cleaner Production, v. 19, n. 11, p. 1229-1238, 2011.

HÁJKOVÁ, P. Kaolinite claystone-based geopolymer materials: effect of chemical composition and curing conditions. Minerals, v. 8, n. 10, p. 17-19, 2018.

HAO, H. et al. Utilization of solar panel waste glass for metakaolinite-based geopolymer synthesis. Environmental Progress \& Sustainable Energy, v. 32, p. 797-803, 2013.

$\mathrm{HE}$, P. et al. Effects of $\mathrm{Si} / \mathrm{Al}$ ratio on the structure and properties of metakaolin based geopolymer. Ceramics International, v. 42, n. 13, p. 14416-14422, 2016.

HOSAN, A.; HAQUE, S.; SHAIKH, F. Compressive behaviour of sodium and potassium activators synthetized fly ash geopolymer at elevated temperatures: a comparative study. Journal of Building Engineering, v. 8, p. 123-130, 2016.

KHALE, D.; CHAUDHARY, R. Mechanism of geopolymerization and factors influencing its development: A review. Journal of Materials Science, v. 42, n. 3, p. 729-746, 2007.

KOLOUŠEK, D. et al. Preparation, structure and hydrothermal stability of alternative (sodium silicate-free) geopolymers. Journal of Materials Science, v. 42, p. 9267-9275, 2007.

LAHOTI, M.; TAN, K. H.; YANG, E. H. A critical review of geopolymer properties for structural fireresistance applications. Construction and Building Materials, v. 221, p. 514-526, 2019.

LECOMTE, I. et al. Synthesis and characterization of new inorganic polymeric composites based on kaolin or white clay and on ground-granulated blast furnace slag. Journal of Materials Research, v. 18, n. 11, p. 2571-2579, 2003.

LIU, Y. et al. An overview on the reuse of waste glasses in alkali-activated materials. Resources, Conservation and Recycling, v. 144, p. 297-309, feb. 2019.

MENEZES, R. M. R. O. et al. Hydraulic binder obtained from recycled cement and sand powder. Revista IBRACON de Estruturas e Materiais, v. 11, n. 6, p. 1178-1185, 2018.

NAZARI, A.; BAGHERI, A.; RIAHI, S. Properties of geopolymer with seeded fly ash and rice husk bark ash. Materials Science and Engineering A, v. 528, n. 24, p. 7395-7401, 2011.

NOVAIS, R. M. et al. Waste glass from end-of-life fluorescent lamps as raw material in geopolymers. Waste Management, v. 52, p. 245-255, 2016.

ONORATO, P. I. K. et al. Bridging and nonbridging oxygen atoms in alkali aluminosilicate glasses. Journal of the American Ceramic Society, v. 68, n. 6, p. C148-C150, 1985.

OZER, I.; SOYER-UZUN, S. Relations between the structural characteristics and compressive strength in metakaolin based geopolymers with different molar Si/Al ratios. Ceramics International, v. 41, n. 8, p. 10192-10198, 2015.

PAVLIN, M. et al. Mechanical, microstructural and mineralogical evaluation of alkali-activated waste glass and stone wool. Ceramics International, fev. 2021.

PIMRAKSA, K. et al. Lightweight geopolymer made of highly porous siliceous materials with various $\mathrm{Na}_{2} \mathrm{O} / \mathrm{Al}_{2} \mathrm{O}_{3}$ and $\mathrm{SiO}_{2} / \mathrm{Al}_{2} \mathrm{O}_{3}$ ratios. Materials Science and Engineering A, v. 528, n. 21, p. 6616-6623, 2011.

PROVIS, J. L. Alkali-activated materials. Cement and Concrete Research, v. 114, p. 40-48, 2018.

PROVIS, J. L.; BERNAL, S. A. Geopolymers and related alkali-activated materials. Annual Review of Materials Research, v. 44, n. 1, p. 299-327, 2014.

158 Alvarenga, C. do B. C. S.; Sales, R. do B. C.; Caldas, R. B.; Cetlin, P. R.; Aguilar, M. T. P. 
PROVIS, J. L.; LUKEY, G. C.; VAN DEVENTER, J. S. J. Do geopolymers actually contain nanocrystalline zeolites? a reexamination of existing results. Chemistry of Materials, v. 17, n. 12, p. 3075-3085, 2005.

PROVIS, J. L.; VAN DEVENTER, J. S. J. Geopolymers, Structures, Processing, Properties and Industrial Applications. Washington, DC: Woodhead Publishing; CRC Press LLC, 2009.

RIAHI, S. et al. The effect of mixing molar ratios and sand particles on microstructure and mechanical properties of metakaolin-based geopolymers. Materials Chemistry and Physics, v. 240, 2020.

ROWLES, M. R. et al. ${ }^{29} \mathrm{Si},{ }^{27} \mathrm{Al},{ }^{1} \mathrm{H}$ and ${ }^{23} \mathrm{Na}$ MAS NMR study of the bonding character in aluminosilicate inorganic polymers. Applied Magnetic Resonance, v. 32, p. 663-689, 2007.

SALES, F. A. Estudo da atividade pozolânica de micropartículas de vidro soda-cal, incolor e âmbar, e sua influência no desempenho de compostos de cimento portland. Belo Horizonte: Universidade Federal de Minas Gerais, 2014.

SCRIVENER, K. L.; NONAT, A. Hydration of cementitious materials, present and future. Cement and Concrete Research, v. 41, n. 7, p. 651-665, 2011.

SI, R. et al. Mechanical property, nanopore structure and drying shrinkage of metakaolin-based geopolymer with waste glass powder. Journal of Cleaner Production, v. 242, 2020.

SINGH, N. B.; KUMAR, M.; RAI, S. Geopolymer cement and concrete: Properties. Materials Today: Proceedings, v. 29, p. 743-748, 2020.

SINGH, N. B.; MIDDENDORF, B. Geopolymers as an alternative to Portland cement: an overview. Construction and Building Materials, v. 237, 2020.

SORE, S. O. et al. Comparative study on geopolymer binders based on two alkaline solutions ( $\mathrm{NaOH}$ and $\mathrm{KOH})$. Journal of Minerals and Materials Characterization and Engineering, v. 8, n. 6, p. 407-420, 2020.

THO-IN, T. et al. Compressive strength and microstructure analysis of geopolymer paste using waste glass powder and fly ash. Journal of Cleaner Production, v. 172, p. 2892-2898, 2018.

TORRES-CARRASCO, M. Reutilización de residuos vítreos urbanos e industriales en la fabricación de cementos alcalinos. Activación, comportamiento y durabilidad. Madrid: Universidad Autónoma de Madrid, 2015.

TORRES-CARRASCO, M.; PUERTAS, F. Waste glass as a precursor in alkaline activation: chemical process and hydration products. Construction and Building Materials, v. 139, p. 342-354, 2017.

VALCKE, S. L. A. et al. FT-IR and 29Si-NMR for evaluating aluminium-silicate precursors for geopolymers. Materials and Structures, v. 48, n. 3, p. 557-569, 2015.

WALKLEY, B. et al. Phase evolution of C-(N)-A-S-H/N-A-S-H gel blends investigated via alkali-activation of synthetic calcium aluminosilicate precursors. Cement and Concrete Research, v. 89, p. 120-135, 2016.

XU, H. et al. Effect of blast furnace slag grades on fly ash based geopolymer waste forms. Fuel, v. 133, p. 332-340, 2014.

YASERI, S. et al. The role of synthesis parameters on the workability, setting and strength properties of binary binder based geopolymer paste. Construction and Building Materials, v. 157, p. 534-545, 2017.

ZHANG, M. et al. A multiscale investigation of reaction kinetics, phase formation, and mechanical properties of metakaolin geopolymers. Cement and Concrete Composites, v. 78, p. 21-32, 2017.

ZHANG, Z. et al. Quantitative kinetic and structural analysis of geopolymers. Part 1. the activation of metakaolin with sodium hydroxide. Thermochimica Acta, v. 539, p. 23-33, 2012.

ZIRL, D. M.; GAROFALINI, S. H. Structure of sodium ahminosilicate glass surfaces David. Journal of the Americun Ceramic Society, v. 62, p. 2353-2362, 1992. 


\section{Cristiane do Bom Conselho Sales Alvarenga}

Departamento de Engenharia de Estruturas | Universidade Federal de Minas Gerais | Av. Antônio Carlos, 6627, Bloco 2, Sala 4108, Pampulha | Belo Horizonte - MG - Brasil | CEP 31270-901 | Tel.: (31) 3409-3589 | E-mail: crisbcs@ufmg.br

\section{Rosemary do Bom Conselho Sales}

Departamento de Projeto e Configuração | Universidade do Estado de Minas Gerais | Rua Gonçalves Dias, 1434, Lourdes | Belo Horizonte MG - Brasil | CEP 30140-091 | Tel.: (31) 98498-8077 | E-mail: rosemary.sales@uemg.br

\section{Rodrigo Barreto Caldas}

Departamento de Engenharia de Estruturas | Universidade Federal de Minas Gerais | E-mail: caldas@dees.ufmg.br

\section{Paulo Roberto Cetlin}

Departamento de Engenharia Mecânica | Universidade Federal de Minas Gerais | Av. Antônio Carlos, 6627, Bloco 2, Sala 3628, Pampulha | Belo Horizonte - MG - Brasil | CEP CEP 31270-901 | Tel.: (31) 3409-4891 | E-nail: pcetlin@demec.ufmg.br

\section{Maria Teresa Paulino Aguilar}

Departamento de Engenharia de Materiais e Construção | Universidade Federal de Minas Gerais | Av. Antônio Carlos, 6627, Bloco 2, Sala 3307, Pampulha | Belo Horizonte - MG - Brasil | CEP 31270-901 | Tel.: (31) 3409-1852 | E-mail: teresa@ufmg.br

\section{Ambiente Construído}

Revista da Associação Nacional de Tecnologia do Ambiente Construído Av. Osvaldo Aranha, $99-3^{\circ}$ andar, Centro

Porto Alegre - RS - Brasil

$$
\text { CEP } 90035-190
$$

Telefone: +55 (51) 3308-4084

www.seer.ufrgs.br/ambienteconstruido www.scielo.br/ac

E-mail: ambienteconstruido@ufrgs.br 